UDC 341.645

CERIF: S150

DOI: $10.5937 /$ AnaliPFB1804127V

Mihajlo Vučić, $\mathrm{PhD}^{*}$

\title{
BINDING EFFECT OF PROVISIONAL MEASURES AS AN INHERENT JUDICIAL POWER: AN EXAMPLE OF CROSS-FERTILIZATION
}

The inherent powers of international courts and tribunals are a necessary consequence of properly exercising judicial functions in the context of a legal system lacking a central legislative power, setting the limits of these functions through firm legal rules. The power to grant binding provisional measures is the most extreme example of international judiciary reaching for inherent powers, since this process disregards ordinary textual interpretations of judicial statutes. At the same time, this process is an example of cross-fertilization between different judicial regimes in international law, where tribunals for the law of the sea influence general international courts, which in turn influence investment and human rights tribunals. The limits to these inherent powers must provide that state consent, as the central tenet of international legal order, remains unaffected. The fact that this practice has not met with resistance from states indicates that international courts and tribunals have assumed this inherent power with propriety and logic.

Key words: $\quad$ Provisional measures. - Inherent powers. - Cross-fertilization.

\section{INHERENT POWERS AND CROSS-FERTILIZATION}

\subsection{General Definition of Inherent Powers}

The inherent powers of any court are derived from its nature. ${ }^{1}$ The court of law must perform certain procedural functions in order to give practice directions, to prevent abuse of court proceedings, to stay

* Research Fellow, Institute of International Politics and Economics in Belgrade, mihajlo@diplomacy.bg.ac.rs. 
proceedings, to correct an injustice caused by an earlier order, or to exercise control over the persons before it. $^{2}$ More specifically, observers have identified four inherent powers flowing from the judicial function: (1) the power to interpret the submissions of the parties in order to isolate the issue(s) in the case and identify the object(s) of the claim; (2) the power to determine whether the court is competent to hear a particular matter; (3) the power to determine whether the court should refrain from exercising the jurisdiction that it has; and (4) the powers to decide all issues concerning the exercising of its jurisdiction, including ruling on issues about evidence, burden of proof, due process, and questions of law relevant to the merits of the dispute. ${ }^{3}$

The inherent powers of a court are a necessary consequence of its established capability to settle a dispute in front of it, i.e. to claim jurisdiction over a dispute. Judicial decisions operate in the framework of legal rules that define points of reference (material law which should be interpreted and applied to particular facts of the case) and operation modalities (formal law, or rules of legal procedure). These points of reference and operation modalities are consigned to a specific field of relations that courts regulate through their judicial activity. This is called the jurisdiction of the court.

\subsection{Inherent Powers of International Courts and Tribunals}

Turning to the jurisdiction of international courts, we must bear in mind that this jurisdiction operates in the field of relations that are international by nature. International relations are characterised by a lack of a central legislative power, which in municipal relations sets the limits of judicial power through firm legal rules. ${ }^{4}$ Furthermore, the subjects of international social relations are by and large states, acting as sovereign and equal entities, creating, through the exercise of their sovereign will, most of the legal rules that regulate these social relations. Two important

1 I. H. Jacob, "The Inherent Jurisdiction of the Court", Current Legal Problems 23(1)/1970, 24.

2 For more see C. Brown, A Common Law of International Adjudication, Oxford University Press, Oxford, 2009, 56, where the author claims that the inherent powers of international courts and tribunals actually have their origins in the practice of English courts.

3 For a more general discussion see D. Shelton, "Form, Function, and the Powers of International Courts", Chicago Journal of International Law 9/2009, 545.

4 As the ICTY Appeals Chamber noted in Tadić "International law, because it lacks a centralized structure, does not provide for an integrated judicial system operating an orderly division of labour among a number of tribunals, where certain aspects or components of jurisdiction as a power could be centralized or vested in one of them but not the others. In international law, every tribunal is a self-contained system (unless otherwise provided)," (ICTY, Prosecutor v. Tadić, 35 ILM 32, 39, 1996). 
consequences derive from these specificities of international relations. First, the jurisdiction of international courts is inevitably consent-based. Second, the rules as points of reference and operation modalities are underdeveloped and incomplete. However, international courts still have to perform their judicial functions in order to satisfy the purpose for which they were created. Therefore, they sometimes reach for certain powers that were otherwise not expressly conferred to them as necessary for the proper fulfilment of their purpose. These are the so-called inherent jurisdictional powers.

This functional justification ${ }^{5}$ for the existence of inherent powers finds support in judicial decisions. The International Criminal Tribunal for former Yugoslavia (ICTY) Appeals Chamber in the Blaškić case held that the "International Tribunal must possess the power to make all those judicial determinations that are necessary for the exercise of its primary jurisdiction." This is in accordance with the interpretation of the International Court of Justice (ICJ) in its famous Nuclear Tests decision, where it referred to the need to safeguard its judicial function: "It should be emphasized that the Court possesses an inherent jurisdiction enabling it to take such action as may be required, on the one hand, to ensure that the exercise of its jurisdiction over the merits, if and when established, shall not be frustrated, and on the other, to provide for the orderly settlement of all matters in dispute, to ensure the observance of the 'inherent limitations on the exercise of the judicial function' of the Court, and to 'maintain its judicial character' ... Such inherent jurisdiction, on the basis of which the Court is fully empowered to make whatever findings may be necessary for the purposes just indicated, derives from the mere existence of the Court as a judicial organ established by the consent of states, and is conferred upon it in order that its basic judicial functions may be safeguarded."7

The World Trade Organization (WTO) Appellate Body also stated that "WTO panels have certain powers that are inherent in their adjudicative function." 8 The Appellate Body in Mexico-Soft Drinks

5 Functional justification of inherent powers is often confused with the notion of implied powers. This is understandable since the two terms are only semantically different. Equally as inherent powers, implied powers of international courts and tribunals are considered to be conferred on the court by the terms of a constitutive instrument, but they are not made express, rather they are conferred by implication. As Lauterpacht noted, this doctrine essentially rests on the principle of effectiveness in treaty interpretation (see $\mathrm{H}$. Lauterpacht, The Development of International Law by the International Court, Cambridge University Press, Cambridge 1982, 227-228).

6 ICTY, Appeals Chamber Judgment, Prosecutor v. Blaškić, 110 ILR 688, 698, 1997.

7 ICJ, Nuclear Tests (Australia v. France), I.C.J. Reports 253, 1974, 259-260.

8 WTO, Mexico - Taxes on Soft Drinks, WT/DS308/AB/R, para 45. 
appears to have preferred the application of inherent powers in relation to the compétence de la compétence doctrine, which enables courts to regulate their own procedure. As a pair of authors point out "The inherent powers approach appears to be a less strained interpretation of the Covered Agreements, although it still requires careful scrutiny of those agreements before applying any principle, as occurred in Mexico."

An analogy in international law may be made in this respect to the implied powers of international organizations. In the Reparations for Injuries Suffered in Service of the United Nations advisory opinion, the ICJ held that the United Nations impliedly has all the powers necessary for the fulfilment of its functions. ${ }^{10}$

\subsection{Inherent Powers and Cross-fertilization in International Law}

The issue that I want to explore in the course of this article is how international courts and tribunals reach for inherent jurisdictional powers. There are many instances in which this mechanism can be observed. Aside from remedies ${ }^{11}$ and evidence, ${ }^{12}$ provisional measures are the most

9 A.D. Mitchell, D. Heaton, "The Inherent Jurisdiction of WTO Tribunals: The Select Application of Public International Law Required by the Judicial Function", Michigan Journal of International Law 31/2010, 570-571.

10 ICJ, Reparations for Injuries Suffered in Service of the United Nations, Advisory Opinion, 1949 I.C.J. Reports 174, 182.

11 The competence of international courts and tribunals to award remedies is based on the inherent power to provide for the orderly settlement of all matters in the dispute. Therefore, these bodies have not declined their jurisdiction to award compensation, satisfaction or reparation even without express authorizations in their constitutive instruments. The Permanent Court of International Justice (PCIJ) has assumed this power already in the Chorzow Factory case, connecting reparation with the need to eliminate all the negative consequences produced by the wrongful act which has been adjudicated and to provide as far as possible the restitution of the state of affairs which would have existed had the wrongful act not been committed (Case concerning the Factory at Chorzów, Judgment, PCIJ Reports 1982, Series A, No. 17, 6). ICJ has followed this practice and ordered in various instances various forms of reparations, designed to efface all the consequences of the breach of an international legal obligation. Some arbitral tribunals have followed suit in cases where they have even encroached upon the judicial decisions of municipal courts, for example the tribunal in the Martini case did when it ordered the annulment of a domestic court judgment. Remedies are certainly part of inherent judicial function since the purpose of a dispute settlement procedure is to repair the wrongs that occurred with the breach of a legal rule, thus strengthening the legal order and focusing on cessation of further breaches. This was noticed as far back as in the case of Caroline arbitration. However, it can be observed that international courts and tribunals have carefully avoided the possibility of inherently assuming power to award punitive remedies, since this would not be in accord with the sovereign equality of states.

12 In order to make whatever findings may be necessary for the purposes of settling a dispute, every court of law, including international one, must act upon the full knowledge of the factual background of the dispute. This knowledge is gained through the procurement of evidence. The evidential procedures in front of international courts and 
extreme example of international courts and tribunals reaching for inherent powers. As will be seen in the course of the article, sometimes the interpretation of the constitutive instruments is so wide that it disregards the ordinary textual interpretation of the statute to give binding effect to provisional measure.

I would like to point out at the same time that this practice represents an example of the process of judicial cross-fertilization in international law. Philippe Sands uses this term to denote the emergence of an increasingly homogeneous body of rules applied by international courts and tribunals, relating to issues of procedure and remedies, both in cases where their constitutive instruments make provision for certain procedures and remedies, and also in cases where there are lacunae in their statutes and rules. ${ }^{13}$ Therefore, I will show, using the example of the interpretation of the binding effect of provisional measures, how international courts and tribunals tend to follow each other's practice concerning the interpretation of inherent powers.

\section{PROVISIONAL MEASURES AND THEIR BINDING QUALITY}

A provisional measure of protection, also known as an interim measure, is a procedural mechanism, which protects the interest in preserving the status quo while a case is pending before the court. Provisional measures seek to "protect the respective rights of the parties and ensure that the final judgment is not rendered ineffective." 14 In the Fisheries Jurisdiction case, for example, the ICJ issued a provisional measure to prevent Iceland from immediately implementing its proposed regulations, because application of the regulations would "prejudice the rights claimed by the United Kingdom and affect the possibility of their full restoration in the event of a judgment in its favour." 15

One can argue that to claim the possibility to grant a binding provisional measure as an inherent power of the court is necessary to

tribunals are usually under-regulated. This is a good opportunity therefore to call upon inherent jurisdictional powers so as to fill in the gaps left by the expressly transferred powers.

13 P. Sands, "Treaty, Custom and the Cross-fertilization of International Law", Yale Human Rights and Development Journal 1/1998, 85.

14 K. Oellers-Frahm, "Expanding the Competence to Issue Provisional MeasuresStrengthening the International Judicial Function", On Public Authority and Democratic Legitimation in Global Governance (eds. A. von Bogdandy, I. Venzke), 2017, 393.

15 ICJ, Fisheries Jurisdiction Case (United Kingdom v. Iceland), 1972 I.C.J. Reports 12, 22. 
ensure that its jurisdiction on the merits shall not be frustrated. ${ }^{16}$ Certainly a provisional measure is an order of urgent nature and it precludes the occurrence of events that might otherwise prejudice the rights and obligations being under dispute. Therefore international courts and tribunals are willing to order them with a slightly lower threshold of subject matter relevance than is needed for decisions on merits. Notwithstanding this, I will show on several examples that international courts and tribunals have often acted ultra vires their competences expressly conferred on them in claiming this inherent power.

\subsection{The ICJ and the Effective Interpretation of its Statute}

Article 41 of the Statute of the ICJ allows the Court to "indicate", on the basis of circumstances of the case, provisional measures which ought to be taken in order to preserve respective rights of the parties. ${ }^{17}$ This is therefore a jurisdictional power expressly conferred upon it by the member parties to its statute. Term indicate would suggest that provisional measures are only recommended to the parties and therefore are not binding. Article 41(2) uses an even weaker wording when it refers to "measures suggested". ${ }^{18}$ However, the ICJ has from the very beginning of its practice regarded the power to award provisional measures as inherently binding.

At first it seemed from the ICJ's reasoning that the binding effect was reserved only for disputes in the field of armed conflict. In the Armed activities in Nicaragua case, the Court stated that: "[w]hen the situation requires that measures under [article 41] should be taken, it is incumbent

16 As Fitzmaurice remarked, the power to indicate interim measures falls into the same category as its compétence de la compétence. While the latter enables the International Court to function at all, the former is intended to prevent its decisions from being stultified. Following this reasoning, Fitzmaurice suggested that

" $[t]$ he whole logic of the jurisdiction to indicate interim measures entails that, when indicated, they are binding - for this jurisdiction is based upon the absolute necessity, when the circumstances call for it, of being able to preserve, and to avoid prejudice to, the rights of the parties, as determined by the final judgment of the Court.

To indicate special measures for that purpose, if the measures, when indicated, are not even binding (let alone enforceable), lacks all point." (G. Fitzmaurice, The Law and Procedure of the International Court of Justice, Cambridge University Press, Cambridge 1986, 542).

17 Statute of the International Court of Justice, https://www.icj-cij.org/en/statute, 20. August 2018, art. 41(1).

18 According to Thirlway, Article 41 in combination with travaux préparatoires, suggests that provisional measures are not binding, "for if the parties to the Statute intended to endow the Court's orders with binding force, they were in position to draft the relevant provisions accordingly, which they did not do," (H. Thirlway, The Law and Procedure of the International Court of Justice, Oxford University Press, Oxford, 2013, 21). 
on each party to take the Court's indication seriously into account, and not to direct its conduct solely by reference to what it believes to be its rights. Particularly is this so, in a situation of armed conflict where no reparation can efface the results of conduct which the Court may rule to have been contrary to international law." 19

However, in the LaGrand case, the Court clarified that the binding character of provisional measures is inherent to its judicial function. This was especially important in view of the fact that Germany had argued that the measures are binding while the United States had taken the view frequently expressed by States so far that the language and history of Article 41 of the ICJ Statute and Article 94 of the Charter of the United Nations show the contrary. The Court for its part does not deal with the term "indicate". It rather puts the main emphasis on the ensuing halfsentence according to which provisional measures "ought" to be taken. From a grammatical point of view this is somewhat confusing, since the drafting history of the ICJ Statute shows the discussion around much stronger French term ordonner had ended in replacing this word by indiquer, which is a synonym for indicate. However, later on, the Court reached a much more logical conclusion that the object and purpose of the Statute is in favour of the binding force of provisional measures.

"The object and purpose of the Statute is to enable the Court to fulfill the functions provided for therein, and in particular, the basic functions of judicial settlement of international disputes by binding decisions in accordance with Article 59 of the Statute. The context in which Article 41 has to be seen within the Statute is to prevent the Court from being hampered in the exercise of its functions because the respective rights of the parties to a dispute before the Court are not preserved. It follows from the object and purpose of the Statute, as well as from the terms of Article 41 when read in their context, that the power to indicate provisional measures entails that such measures should be binding, inasmuch as the power in question is based on the necessity, when the circumstances call for it, to safeguard, and to avoid prejudice to, the rights of the parties as determined by the final judgment of the Court. The contention that provisional measures indicated under Article 41 might not be binding would be contrary to the object and purpose of that Article." 20

This "object and purpose" interpretation, ${ }^{21}$ is in line with our conception of inherent powers as a functional necessity for the operation

19 ICJ, Military and Paramilitary Activities in and against Nicaragua (Nicaragua v. United States of America), Merits, judgment of 27 June 1986, I.C.J. Reports 1986, 14, 144.

20 ICJ, LaGrand Case (Germany v. United States of America), 2001 I.C.J. Reports 466, 502-503. See also S. Rosenne, The Law and Practice of the International Court 1920-2005, Martinus Nijhoff, Brill, 34-40.

21 The Court in reality adopted the stance prescribed by Article 33 of the 1969 Vienna Convention on the Law of Treaties which gives priority to the text more favourable 
of a court of law. In the later instances of indication of provisional measures there were no disputes regarding their binding effect.

For example, in the Temple of Preah Vihear case, Cambodia and Thailand have been engaged in a long-standing territorial dispute over land in the vicinity of the temple of Preah Vihear, which is located near the countries' shared border. In July 2011, the ICJ, in connection with a request for interpretation of its 1962 judgment, indicated provisional measures, ordering the respondent to withdraw its forces from the territory of the disputed monastery, thus creating a demilitarized zone around the temple and steering both countries to cooperation with the help of the Association of Southeast Asian Nations (ASEAN). As one author notes: "The establishment of this demilitarized Zone, which included territory not subject to overlapping claims, was hotly contested among judges on the court, raising broader questions about the scope of the court's authority to issue provisional measures. Additionally, the court's inclusion of ASEAN as a body to facilitate resolution of the dispute fashioned the provisional measures into a channel for integrated dispute resolution, pairing adjudication with mediation." 22

In 2011 as well, the ICJ gave its decision on provisional measures in the Nicaragua/Costa Rica dispute, agreeing to a request by Costa Rica, calling on Nicaragua to withdraw its troops or any personnel engaged in building the disputed canal, felling trees or dumping sediment from the disputed area. The ICJ further indicated that neither state should send any civilian, military or police personnel into the disputed area until the boundary dispute is resolved. An exception was made for civilian officials from Costa Rica to ensure protection of the wetlands. ${ }^{23}$

In one of the most recent cases, the ICJ returned to questions that occurred in LaGrand. On May 18, 2017, the Court granted provisional measures in the Jadhav case brought by India against Pakistan. ${ }^{24}$ In line with LaGrand, the Court approached the request for interim relief in a death penalty case. The Court ordered Pakistan to stay the execution of Kulbhushan Jadhav, an Indian national, pending a final decision in the proceedings instituted by India. It reiterated that orders on provisional measures are binding on the parties to whom they are addressed.

to the object and purpose of a treaty. See more A. Orakhelashvili, "Questions of International Judicial Jurisdiction in the LaGrand Case", Leiden Journal of International Law 15/2002, 116.

22 A.C. Traviss, "Temple of Preah Vihear: Lessons on Provisional Measures", Chicago Journal of International Law 13(1)/2012, 12.

23 ICJ, Certain activities carried out by Nicaragua in the Border Area (Costa Rica v. Nicaragua, Request for indication of provisional measures, Order of 8 March 2011, I.C.J. Reports 2011, p. 6.

24 ICJ, Jadhav Case (India v. Pakistan), Order on Provisional Measures (May 18, 2017), http://www.icj-cij.org/files/case-related/168/168-20170518-ORD-01-00-EN.pdf, 20. August 2018. 
It is interesting to note that these provisional measures, if disregarded by addressees, can be enforced by the UN Security Council by virtue of functional interpretation of articles 41(2) of the Statute and 94(2) of the Charter of the United Nations. It is doubtful whether this would actually happen since the record of SC enforcement of ICJ decisions is so far non-existent. ${ }^{25}$

\subsection{The ITLOS and Express Statutory Authority}

The ICJ was not alone in assuming inherent powers concerning provisional measures. The tribunals for the law of the sea have been enabled by the provisions of the United Nations Convention for the Law of the Sea (UNCLOS) ${ }^{26}$ to prescribe binding provisional measures, and used it extensively especially in relation to prompt releases of $\operatorname{ships}^{27}$, or preservation of marine resources ${ }^{28}$. Article 290 of the UNCLOS gives the power to "prescribe" provisional measures. This difference to the ICJ's statute is further reinforced by paragraph 6 of Article 290, which states "the parties to the dispute shall comply promptly with any provisional measures prescribed under this article". The logical implication of these provisions is that the provisional measures under Article 290 of the Convention are binding on the parties to whom they are addressed. I agree partially with authors who claim that the ICJ was prompted by the ITLOS's ability to grant binding provisional measures to try to "remain an attractive forum for cases involving requests for provisional measures." 29 In addition, I regard the ICJ's unequivocal interpretation of provisional measure's effect in LaGrand as an example of cross-fertilization from the jurisprudence of the law of the sea to general international law jurisprudence.

25 See further in C. Paulson, "Compliance with Final Judgments of the International Court of Justice since 1987", The American Journal of International Law 98(3)/2004), 434-461, who writes that "states have not been subject to Security Council sanctions for non-compliance."

26 United Nations Convention on the Law of the Sea of 10 December 1982.

27 In the MIV SAIGA case, ITLOS ordered the respondent to "refrain from taking or enforcing any judicial or administrative measures against the ship, its Master and the other members of the crew, its owners or operators, in connection with the incidents leading to the arrest and detention of the vessel and the subsequent prosecution and conviction of the Master" (ITLOS, MIV SAIGA (No. 2), provisional measures, order of 11 March 1998, para 21(1) (a)).

28 In the Southern Bluefin Tuna case, ITLOS noted that the parties were agreed that the stock of southern bluefin tuna was "severely depleted and [was] at its historically lowest levels and that this [was] a cause for serious biological concern", Order of 27 August 1998, para. 71.

29 C. Romano, "The Southern Bluefin Tuna Dispute: Hints of a World to Come ... Like It or Not", Ocean Development and International Law 32(4)/2001, 313. 


\subsection{The ICSID tribunals and "Creative" Statutory Interpretation}

While the previous example of the ICJ's behaviour might be widely construed as praeter legem jurisprudence, investment arbitration tribunals under the International Convention for Settlement of Investment Disputes (ICSID) convention have pushed this even further, one might say even contra legem, when they started substituting recommendatory nature of provisional measures from the Convention's text with binding nature in their decisions.

The ICSID Convention expressly authorizes a tribunal to "recommend" provisional measures. The relevant provision is Article 47: "Except as the parties otherwise agree, the Tribunal may, if it considers that the circumstances so require, recommend any provisional measures which should be taken to preserve the respective rights of either party." 30 The negotiating history of the Convention also testifies that tribunals were supposed to issue only non-binding provisional measures. ${ }^{31}$

Despite all these express limitations, ICSID tribunals have consistently found that such measures are very much binding. The Tribunal in the Maffezini case, for example, felt free to claim that the word recommend used in Article 47 and Rule 39 of the ICSID Arbitration Rules, is equivalent to the word order and that "the tribunal's authority to rule on provisional measures is no less binding than that of a final award." 32 This claim has been consistently followed, as for example in the case of Pey Casado, where the Tribunal gave a good example of cross-fertilization practice when it pointed out the fact that Article 47 of the Convention was not an innovation but was inspired by Article 41 of the Statute of the ICJ. ${ }^{33}$ According to the Tribunal, decisions of the ICJ and its predecessor, Permanent Court of International Justice, should therefore be taken into consideration when interpreting Article 41. ${ }^{34}$ This decision did not escape critique from several commentators, ${ }^{35}$ which in

30 Convention on the Settlement of Investment Disputes between States and Nationals of Other States (opened for signature 18 March 1965, entered into force 14 October 1966, ICSID Convention).

31 ICSID, History of the ICSID Convention: Document Concerning the Origin and the Formulation of the Convention on the Settlement of Investment Disputes between States and Nationals of Other States, ICSID Publication, 1968, Washington, D. C., vol. II, docs $132,987$.

32 ICSID, Emilio Agustín Maffezini v. Kingdom of Spain, ICSID Case No. ARB/97/7, Procedural Order No. 2 (28 October 1999) para. 9.

33 ICSID, Victor Pey Casado and President Allende Foundation v. Republic of Chile, ICSID Case No. ARB/98/2, Decision on Provisional Measures (25 September 2001) para. 2.

34 Ibid, paras. 2, 18-19, 20-6.

35 For the overview see D.F. Donovan, "Provisional Measures in the ICJ and ICSID: Further Dialogue and Development", Contemporary Issues in International 
turn did not prevent repeated decisions by ICSID tribunals to endorse the same view. Therefore we can speak currently of a certain jurisprudence constante on the binding force of provisional measures in the framework of the ICSID. ${ }^{36}$

\subsection{Human Rights Courts as Pioneers}

Although I will present them at the end of this analysis, regional human rights courts in their practice blazed the trail that other international courts and tribunals have consequently only followed. The Inter-American Court of Human Rights was the first among the international tribunals explicitly to hold that its provisional measures orders are binding and mandatory, only a year before the LaGrand decision. In the Constitutional Court case, in which judges of the Peruvian Constitutional Court had been illegally removed from office, the Inter-American Court held that the American Convention provision "makes it mandatory for the state to adopt the provisional measures ordered by this Tribunal." ${ }^{, 37}$ It grounded its decision in "a basic principle of the law of international state responsibility, supported by international jurisprudence, according to which States must fulfil their conventional international obligations in good faith (pacta sunt servanda)." ${ }^{38}$ In the words of one author: "The Court's pronouncement in the Constitutional Court case is unequivocal, permitting no measure of doubt as to the Court's resolution of this question." 39

Although The European Court of Human Rights (ECtHR) in Cruz Varas assumed that "no assistance can be derived from general principles of international law since [...] the question whether interim measures indicated by international tribunals are binding is a controversial one and

Arbitration and Mediation: The Fordham Papers 2012 (ed. A.W. Rovine), Martinus Nijhoff, Brill 2013, 100.

36 See Tokios Tokelés v. Ukraine, ICSID Case No. ARB/02/18, Procedural Order No. 1 (1 July 2003) paras. 2, 4; Helnan International Hotels A/S v. Arab Republic of Egypt, ICSID Case No. ARB/05/19, Claimant's Request for Provisional Measures (17 May 2006) para. 32; Perenco Ecuador Limited v. Republic of Ecuador and Empresa Estatal Petróleos del Ecuador, ICSID Case No. ARB/08/6, Decision on Provisional Measures (8 May 2009) para. 66-77; Tethyan Copper Company Pty Limited v. Islamic Republic of Pakistan, ICSID Case No. ARB/12/1, Decision on Claimant's Request for Provisional Measures (13 December 2012) para. 120; City Oriente Limited v. Republic of Ecuador and Empresa Estatal Petróleos del Ecuador (Petroecuador), ICSID Case No. ARB/06/21, Decision on Provisional Measures (9 November 2007) para. 92.

37 IACtHR, Constitutional Court (Peru), Provisional Measures, Order of Aug. 14, 2000, Inter-Am. Ct. H.R. (ser. E), 14 (2000).

38 Ibid.

39 J. M. Pasqualucci, "Interim Measures in International Human Rights: Evolution and Harmonization", Vanderbilt Journal of Transnational Law 38(1)/ 2005, 23. 
no uniform legal rule exists." ${ }^{40}$ After the LaGrand decision it retracted this and held in Mamatkulov and Abdurasulovic v. Turkey that states must comply with ordered provisional measures "and refrain from any act or omission that will undermine the authority and effectiveness of the final judgment." ${ }^{41}$ Therefore, the ECtHR informed Turkey that it should delay extradition of the applicants (members of an Uzbek opposition party, arrested in Turkey pursuant to international arrest warrants charging them with homicide and a terrorist attack against the President of Uzbekistan) pending the Court's decision in the case. Although most states previously voluntarily complied with ECtHR's indications of interim measures, Turkey did not. The European Court, relying on general principles of law and citing the jurisprudence of several international courts and enforcement bodies, held that Turkey's failure to comply with the Court's indication of interim measures resulted in a breach of its obligations under the European Convention. ${ }^{42}$ It unequivocally stated that a state party must comply with interim measures, arguing that when a state ratifies a treaty and accepts the competence or jurisdiction of the tribunal charged with the enforcement of the rights protected in the treaty, the state must comply in good faith, not only with the substantive provisions of the treaty, but also with its procedural and regulatory provisions. ${ }^{43}$

\section{LIMITS OF THE INHERENT POWER TO GRANT BINDING PROVISIONAL MEASURES}

However important for proper exercise of judicial function, inherent powers still must have limits defined by the need for maintenance of the judicial character of international courts. Although the theory known as compétence de la compétence, i.e. that every court can decide on its own competence to decide a dispute, was confirmed by the ICJ in the case of Nottebohm, ${ }^{44}$ there still exist certain limitations to these inherent powers, whose existence is vital in order for the court to refrain from assuming the role of lawmaker and to maintain its judicial character.

The main question is whether inherent powers might move beyond state consent, as is obviously the case in instances where provisional

40 ECtHR, Cruz Varas v. Sweden, Judgment of 20 March 1991, ECHR (Ser. A201) 4,34 .

41 See ECtHR, Mamatkulov \& Abdurasulovic v. Turkey, App. Nos. 46827/99, 46951/99 (Eur. Ct. H.R. Feb. 6, 2003), 110.

42 Ibid, 111.

43 Ibid, 109.

44 With an important caveat of "the absence of agreement to contrary," see ICJ, Nottebohm, 1953 I.C.J. Reports 111, 119. 
measures were assumed by international courts and tribunals to have binding, effect although that was not the express meaning attached to them in the constitutive instruments of these bodies. This dilemma was recently explored by ICJ Judge Cançado Trindade in his questions put to Nicaragua and Colombia in Sovereign Rights and Maritime Spaces in the Caribbean case. Nicaragua offered the understanding that inherent powers, irrespective from what is provided distinctly in statutes of international tribunals, ensue from their very existence, and they are all endowed with the compétence de la compétence, while Colombia took the view that inherent powers are exercised when necessary, in the interests of the sound administration of justice and that they do not amount to compétence de la compétence. ${ }^{45}$

Firstly, it is an established international legal principle, confirmed by the ICJ in the Northern Cameroons case, that the judiciary is not always bound to exercise its jurisdiction. ${ }^{46}$ Although this limitation is concerned more with the general bar to the exercise international jurisdiction, I find that Brownlie's remark that reasons of judicial propriety are one example of this, ${ }^{47}$ is especially applicable to the case of binding provisional measures. Provisional measures should be indicated only if rights otherwise claimed would be prejudiced and the possibility of their full restoration affected.

Secondly, the particular functions of each international court or tribunal will determine the scope of its inherent powers. ${ }^{48}$ Obviously when granting binding provisional measures, all international courts and tribunals serve the same function - indication of measures that are not even binding (let alone enforceable), lacks all point.

Thirdly, when constitutive instruments do not expressly exclude the exercise of a certain procedural power, the procedures actually provided for it must not be inconsistent with the exercise of that power. This is the reason why it would be inconceivable for WTO bodies to claim powers to grant binding provisional measures. As Brown notes, "the non-availability of retrospective remedies in WTO dispute settlement might permit the inference to be drawn that WTO panels do not have an

45 ICJ, Alleged Violations of Sovereign Rights and Maritime Spaces in the Caribbean Sea (Nicaragua v. Colombia), Judgment of 17 March 2016, Separate opinion of Judge Cançado Trindade, 48, https://www.icj-cij.org/files/case-related/155/15520160317-JUD-01-01-EN.pdf, 20. August 2018.

46 ICJ, Northern Cameroons (Cameroon v. United Kingdom), Judgment of 2 December 1963, 1963 I.C.J. Reports, 29.

47 J. Crawford, Brownlie's Principles of Public International Law, Oxford University Press, Oxford, 2012, 457-483.

48 P. Gaeta, "Inherent powers of International Courts and Tribunals", Man's Inhumanity to Man: Essays on International Law in Honour of Antonio Cassese (eds. L. C. Vohrar et al), 2003, 370. 
inherent power to preserve the rights of the parties during the pendency of the proceedings, for there is no right to compensation for any damage to the complainant state which occurs prior to the adoption of the report". 49

\section{CONCLUSION}

In between interpreting its judicial role inherently so as to provide itself with the powers necessary to ensure the exercise of its jurisdiction on the merits, and on the other hand maintaining its judicial character and staying within the confines of its judicial function, an international court is walking a thin line. The court is not a creator of law, even in the international legal system where the central legislator is conspicuously missing. The court is an interpreter and applier of an imperfect legal framework, which needs constant improvement and concretisation to successfully perform its function: keeping international relations ordered and peaceful. In this course of activity it sometimes decides the case by reaching for powers inherent to the essence of a judicial function. This decision therefore forms a kind of a jurisprudence constante from which it rarely, if ever, departs. ${ }^{50}$

Provisional measures are an example of this jurisprudence. From the various analysed international judicial regimes, only the UNCLOS system expressly provides the power to grant binding provisional measures. The ICJ has used the rule of interpretation for treaties to bypass the not-so-clear textual provision and claim the same power for itself. As the main judicial organ of the most important international organization, it was both influenced by the practice of the tribunals for the law of the sea, and in turn influenced the investment tribunals and regional courts for human rights to follow suit, although they lacked any express competence in their constitutive instruments granting binding measures. Only the WTO system remains so far immune from the effects of this cross-fertilisation, due to its particularities in the dispute settlement mechanism.

The fact that this practice has not met with resistance from subjects of international law that have been affected by these decisions, speaks for itself about its propriety and logic.

\section{C. Brown, 135.}

50 As the ICJ has itself indicated, the departure from such jurisprudence would occur only if the needs of international life fundamentally request it, ICJ, Application of the Convention on the Prevention and Punishment of the Crime of Genocide (Croatia v. Serbia), Preliminary Objections, Judgment, I.C.J. Reports 2008, 412. 


\section{REFERENCES}

Brown, C., A Common Law of International Adjudication, Oxford University Press, Oxford, 2009.

Crawford, J., Brownlie's Principles of Public International Law, Oxford University Press, Oxford, 2012.

Donovan, D. F., "Provisional Measures in the ICJ and ICSID: Further Dialogue and Development", Contemporary Issues in International Arbitration and Mediation: The Fordham Papers 2012 (ed. A.W. Rovine), Martinus Nijhoff, Brill 2013.

Fitzmaurice, G., The Law and Procedure of the International Court of Justice, Cambridge University Press, Cambridge 1986.

Gaeta, P., "Inherent powers of International Courts and Tribunals", Man's Inhumanity to Man: Essays on International Law in Honour of Antonio Cassese (eds. L. C. Vohrar et al), 2003.

ICSID, History of the ICSID Convention: Document Concerning the Origin and the Formulation of the Convention on the Settlement of Investment Disputes between States and Nationals of Other States, ICSID Publication, Washington, D. C. 1968.

Jacob, I. H., "The Inherent Jurisdiction of the Court", Current Legal Problems 23(1)/1970, 23-52.

Lauterpacht, H., The Development of International Law by the International Court, Cambridge University Press, Cambridge 1982.

Mitchell, A. D., D. Heaton, “The Inherent Jurisdiction of WTO Tribunals: The Select Application of Public International Law Required by the Judicial Function", Michigan Journal of International Law $31 / 2010$.

Oellers-Frahm, K., "Expanding the Competence to Issue Provisional Measures-Strengthening the International Judicial Function", International Judicial Lawmaking: On Public Authority and Democratic Legitimation in Global Governance (eds. A. von Bogdandy, I. Venzke), 2017.

Orakhelashvili, A., "Questions of International Judicial Jurisdiction in the LaGrand Case", Leiden Journal of International Law 15/2002.

Pasqualucci, J. M., "Interim Measures in International Human Rights: Evolution and Harmonization", Vanderbilt Journal of Transnational Law 38(1)/ 2005.

Paulson, C., "Compliance with Final Judgments of the International Court of Justice since 1987", The American Journal of International Law 98(3)/2004.

Romano, C., "The Southern Bluefin Tuna Dispute: Hints of a World to Come ... Like It or Not", Ocean Development and International Law 32(4)/2001. 
Sands, P., "Treaty, Custom and the Cross-fertilization of International Law", Yale Human Rights and Development Journal 1/1998.

Shelton, D., "Form, Function, and the Powers of International Courts", Chicago Journal of International Law 9/2009.

Thirlway, H., The Law and Procedure of the International Court of Justice: Fifty Years of Jurisprudence, Oxford University Press, Oxford, 2013.

Traviss, A. C., "Temple of Preah Vihear: Lessons on Provisional Measures", Chicago Journal of International Law 13(1)/2012.

Article history:

Received: 17. 8. 2018.

Accepted: 29. 11. 2018. 